\title{
Teachers' technology adoption and practices: Lessons learned from the IWB phenomenon
}

\author{
Matthew Kearney ${ }^{a *}$, Sandy Schuck ${ }^{\mathrm{a}}$, Peter Aubusson ${ }^{\mathrm{a}}$, and Paul F. Burke ${ }^{\mathrm{b}}$ \\ ${ }^{a}$ STEM Education Futures Research Centre, University of Technology Sydney (UTS), \\ Australia; \\ ${ }^{\mathrm{b}}$ Business Intelligence and Data Analytics (BIDA) Research Centre, UTS Business School, \\ UTS, Australia.
}

*Corresponding author. Email: matthew.kearney@uts.edu.au

The 21st Century has seen unprecedented investment from governments around the world in educational technologies in schools. This paper investigates Australian teachers' adoption and use of a popular technology that has been extensively supported by governments and school systems: the interactive whiteboard (IWB). The study suggests that a number of the barriers identified in the early days of adoption and use of this technology, such as professional support and access, still remain for many teachers, thereby impeding effective practices. The research also found that primary school teachers were using the technology in diverse ways, in contrast to secondary teachers who were using the IWB mainly for instructionist, presentational purposes. We conclude by considering various ways of reducing the effect of the identified barriers to support implementation of educational technologies in the classroom, especially the next generation of technologies promoted by governments and systems.

Keywords: Technology adoption barriers and enablers, teacher integration of technology, educational technologies, professional learning, interactive whiteboards

\section{Introduction}

Digital technologies are becoming ubiquitous in society (Royle, Stager, and Traxler 2014) and this trend has led to government initiatives to embed them in curricula and in pedagogical approaches. Governments often champion a particular technology and then support the adoption of that technology in schools, both financially and through curricula. Such top-down implementation has occurred in the case of the interactive whiteboard (IWB), for example, in the United Kingdom, Denmark and Australia (Clarke 2004; Department of Education, Employment and Workplace Relations 2010; Wong, Teo, and Goh 2014). This type of government promoted implementation is in contrast to more grounded, bottom-up initiatives, such as use of mashups and social media for learning (Bull et al. 2008; Greenhow and Lewin 2016).

Any investment by government in learning technologies has a cost in terms of time and resources (Newhouse 2014), and so implementations must be critiqued to assess whether the benefits outweigh the costs (Weston and Bain 2010). This study examines the experiences of teachers as they implement a popular technology, the interactive whiteboard (IWB), with a view to critically analysing the barriers and enablers affecting teacher adoption of this technology. While IWBs are now a somewhat dated technology, their large-scale promotion by governments in Australia and their widespread use in schools make their uptake of interest. Further, IWBs are deemed to be a 'non-disruptive' technology, that is, one that appears to 
replicate the status quo in pedagogy (Schuck and Kearney 2008). Insights about their adoption provide lessons for future integration of new learning technologies in school education.

Historically, the integration of new educational technologies into classroom practice has been slow (Cuban, Kirkpatrick, and Peck 2001; Dunn and Rakes 2010; Ertmer 2005). Knowing what factors influence teachers' adoption of technologies is useful for education leaders and policy-makers who wish to promote technology integration in the classroom. Teachers make decisions about adoption and use of technologies influenced by a variety of factors such as their beliefs (Blackwell, Lauricella, and Wartella 2014; Ertmer et al. 2012), within a framework of school technology provision and access (Perrotta 2013). Teo (2014) provides a model of technology acceptance that comprises five factors: "perceived usefulness; perceived ease of use; attitude towards technology use; subjective norm; and facilitating conditions" (128). Subjective norm is broadly described as the "extent to which an individual is motivated to comply with the views others hold about the behaviour" (128). These factors align with Ertmer et al.'s (2012) identification of important influences comprising beliefs and school conditions. While Teo's technology acceptance model was originally developed for student teachers, he has validated it with practising teachers. However, he has indicated limitations with the model, one of which is the lack of distinction of specific technologies in the model. Teo (2014) suggests that further research with particular technologies would be valuable.

This paper reports on findings from a recent study investigating the adoption of and practices with IWBs by teachers in primary and secondary education. The paper considers this technology adoption in the aftermath of extensive rollouts in Australian schools. In such a context, it might be expected that access and other first order barriers such as professional development have been ameliorated by the extensive top-down support for use of this technology, and that second order barriers such as teacher beliefs would not be challenged by the non-disruptive nature (Hedberg 2006) of the technology, thus leading to strong uptake. The study investigated these assertions. Therefore, the research question that this paper seeks to answer is: 'What can be learnt about teacher adoption of externally endorsed technologies, using the IWB as a case?' This research sets out to interrogate the current barriers and facilitators for use of IWBs by exploring Australian primary and secondary teachers' experiences, attitudes, and preferences concerning the use of this technology in the classroom.

\section{Context of this study}

Australian school education provides a fertile, authentic case for research in the area of teachers' technology adoption, in particular their adoption of IWBs, given this technology's top-down support by governments and systems. The initial literature on IWBs came predominantly from research in the UK. The UK government had invested heavily ( $£ 50$ million) in the installation of IWBs in schools, with a view to influencing teaching and learning (Clarke 2004). In Australia IWBs became commonplace in schools shortly thereafter. Over a decade later, it is timely to revisit the perceived impact of IWBs after strong government support for embedding them into classrooms and practice in Australian schools. For example in 2011, the New South Wales (NSW) state government in Australia announced that it had rolled out 4,300 new IWBs to classrooms in 1,000 NSW government schools. Schools raised considerable funds to supplement these government initiatives. NSW schools purchased four times the number of IWBs provided directly by the government. In light of these significant national policy and resource initiatives, this study provides a timely contemporary snapshot of 
Australian teachers' perspectives on their practices and experiences, with implications for how school leaders might invest in the next wave of educational technologies to be used in the formal years of school education, from Kindergarten to the final compulsory year of schooling (referred to as K-12 in this paper, with 'primary' being K-6 and 'secondary' being 7-12).

\section{Background}

\section{Barriers and enablers in technology adoption and practice}

The literature has much to say about the integration of learning technologies into teacher practice. Ertmer's seminal study in 1999 identified two types of barriers that exist in teacher adoption of new technology in the classroom. These are classified as first order and second order barriers. First order barriers include external factors such as resources, access, professional development and school support and second order barriers include internal factors such as teacher beliefs, pedagogical approaches and competency with the technology (Ertmer 1999). A recent study by Ertmer et al. (2012) revisited these barriers. They argued that many of the first order barriers identified in the earlier paper (Ertmer 1999) have been removed in the majority of schools. Consequently, they wished to investigate if first order barriers were exerting the same influence as in their earlier study, and to explore the extent to which reduction of external barriers impinged on the alignment of teacher beliefs and practice. In a small-scale study with 12 teachers who evidenced award-winning technology practices, they found that there was an alignment between teachers' student-centred beliefs and practices, which appeared to be independent of the presence of any first order barriers. The authors also suggested that the most important barriers for teachers in using technology were their prevailing beliefs, attitudes and competencies concerning technology. They recommended that professional development should focus on changing teacher beliefs as well as learning how to use the technology well. Similarly, Blackwell et al. (2014) conducted a survey of over 1000 early childhood educators to explore the relationship between extrinsic and intrinsic factors influencing their technology use. They found that teachers' attitudes toward the value of technology to aid children's learning had the strongest effect on technology use. Their findings support findings of earlier studies on the importance of second order barriers in technology integration in classrooms (Ertmer et al. 2012; Ertmer and Ottenbreit-Leftwich 2010).

Other authors note the mix of first and second order factors in influencing teacher technology use. Voogt and Knezek (2008) indicated that teachers' use of ICT is affected by their attitudes, competence, and access to technology. The first two are seen as second order barriers, the last as a first order barrier. Buabeng-Andoh (2012) agrees by suggesting significant barriers that affect teachers' integration of technology occur at the personal, institutional and technological level. They include teacher self-efficacy, professional development opportunities, the support of school leaders, accessibility of the technology and technical support.

We now turn to investigating the presence of such barriers in a specific technology, the IWB. Our study probes teachers' perceptions of these first and second order barriers or enhancers in relation to their use of IWBs. It explores the current barriers and enablers influencing teacher use of the IWB. It seemed likely that the extensive top-down support for IWBs in schools would create a context in which Ertmer's et al. (2012) findings are confirmed, that is, that first-order barriers have been addressed to a large extent and it is the second order barriers of beliefs, attitudes and competencies that mainly dictate teachers' integration of technology. The paper investigates if this premise is supported. 


\section{Use of IWBs across primary and secondary education}

As noted previously in this paper, the introduction of IWBs was strongly led and supported by governments. The top-down implementation in the UK was examined by Gillen et al. (2007) to see whether it was driven by technological or pedagogical considerations. They found that while the IWB might be used effectively in a technical sense, they were not transforming pedagogy. Kennewell (2006), in a meta-analysis of research on interactive whiteboards, noted that unlike adoption of other ICTs, IWBs have met with widespread interest and high rates of adoption in schools. However, he points out that despite the huge uptake of this technology, "to date, the top-down policy driven approach to pedagogical change, represented by the National Strategies in England, seems to have stalled at the stage of surface interactivity which is reflected in replicatory use of IWBs" (7). Kennewell concluded by suggesting that IWBs potentially can be more than a tool to support outmoded pedagogies, while Higgins, Beauchamp, and Miller (2007) and Hennessey and London (2013) highlighted a lack of evidence on improved student achievement. These questions were taken up in Schuck and Kearney (2008) where it was suggested that IWBs generally did not tend to disrupt traditional pedagogies, a claim supported by Gray (2010), who found that teachers appropriated the IWB to serve their own needs and Gillen et al. (2007) who found that transformative teaching was not increased by IWB use. However, the distinctive features of the IWB such as its multimodal capacity and ability to provide motivational lessons have led to the claim that teaching and learning have been improved by its use (Wong, Teo, and Goh 2014). In the previous study by two of the authors of this paper (Kearney and Schuck 2008), the IWB could be seen as a portal to use more emancipatory pedagogies, if effective professional development and learning was in place.

\section{Professional development with IWBs}

Professional development is widely claimed as the pathway to teachers' effective use of technology to influence positive changes to learning (Hennessey and London 2013). In this regard, a number of studies have stressed the importance of teacher professional learning as a key to future practice with IWBs and related technologies (e.g. Warwick and Kershner 2008). Winzenried, Dalgarno, and Tinkler (2010) suggested that IWBs can be used initially without requiring teachers to transform their pedagogies, but transformational pedagogical changes may occur over time. Sweeney (2010) suggested that a 'break-through' phase of teachers' pedagogical development in this area is likely to occur when teachers move beyond the use of native IWB software, while Bennett and Lockyer (2008) found that teachers in their study employed familiar teaching approaches with IWBs that were consistent with approaches they already used. However, they suggested that once IWBs were adopted, "there may be potential for the gradual introduction of new pedagogical approaches as part of an evolutionary rather than revolutionary development of teachers' skills" (298).

In line with Ertmer's first and second order barriers, Cogill (2010) presented a theoretical model for teachers' pedagogic change subsequent to IWB intervention. She espoused the importance of background factors, such as a teacher's beliefs, experiences and the educational context of IWBs. Use of the IWB can help change teachers' pedagogical practice through their planning and preparation, selection of classroom resources and abilities to teach for interactive learning. Türel and Johnson (2012) investigated the relationship between teachers' use of IWBs, their perceptions, competencies and discipline areas and found moderate correlations between these. An important finding was the need for professional 
development support for teachers to develop more constructivist technology-mediated approaches. More recently, studies (Ayhan Kursat, Muge, and Sukru 2015; Hillman 2014) highlighted the role of students in shaping the way that technology is used in a classroom (in this case, the IWB and graphic calculators). These studies indicate that there is a range of ways in which teachers can be supported in using technologies such as the IWB in rich pedagogical ways. These include using the IWB as a portal for their professional learning through the access to online resources and shared materials (Schuck and Kearney 2008), learning in situ supported by peers and colleagues, and student feedback (Ayhan Kursat et al. 2015; Hillman 2014).

The current context of IWB provision in schools demonstrates top-down support, and the presence of the subjective norm (Teo 2014) for teachers to adopt IWBs in their practice. Further, access to the technology has been provided by schools and systems. Provision of professional learning groups by the commercial providers of the IWB is also offered. Consequently, given that the support above exists, it was of interest to investigate the current barriers and enablers.

\section{Study design}

The research question guiding this investigation was: 'What can be learned about teacher adoption of externally endorsed technologies, using the IWB as a case?' A mixed methods approach combining qualitative and quantitative methods was used in this study. The qualitative component drew on interpretive study traditions (Erickson 1986) to investigate teachers' rationales for using IWBs, and their reported practices with IWBs. In an interpretive study, data are collected in a naturalistic way and analysed from an ontological position that recognises 'multiple truths' (Lincoln and Guba 1985). The study's methodology was underpinned by socio-cultural theory, which acknowledges the importance of the context in which the learning takes place and the social embeddedness of the tools (Salomon and Perkins 1998). Data on teachers' beliefs and practices were collected and analysed from this sociocultural perspective.

\section{Participants}

Mixed methods were used to elicit teachers' perspectives through focus group data collection and a national online survey. There were five focus groups comprising a total of 35 teacher participants from government and non-government schools in Australia. The data from these focus groups informed the development of the online survey.

The survey collected information from 200 teachers drawn from an Australia-wide commercial webpanel to investigate attitudes and beliefs, access, and use of IWBs. In both the focus group and survey, participants were split almost evenly between primary and secondary teachers. Eleven respondents to the survey said they taught in both primary and secondary contexts. Survey participants taught across a range of school systems (67 percent from Government schools) throughout Australia. Forty-seven percent of survey respondents had more than 10 years' teaching experience. The sample consisted of approximately 75 percent female teachers and 25 percent male teachers, with a greater proportion of females in primary schools. This aligns with the gender breakdown of the teaching population. Fifty-seven percent of teachers were full-time and the remaining teachers were mainly part-time ( 23 percent) or casual/supply teachers (13 percent). Sixty-eight percent of teachers were from metropolitan schools, 27 percent provincial and 6 percent from remote schools. 
Table 1 shows the distribution of experience with IWBs amongst survey participants. Primary school teachers in the study were more likely to classify themselves as 'intermediate' IWB users and less likely to be 'novice' users (i.e. introductory) compared with secondary teachers (p-value of 0.0186). The percentages of advanced users were the same for primary and secondary teachers.

[Insert Table 1. Participants' IWB experience level ( $n=117$ primary; $n=94$ secondary). ]

\section{Methods}

The focus groups elicited responses concerning teachers' use of IWBs, their rationale for this use, and the facilitating factors and impedances underlying their pedagogical choices. The focus groups provided insightful data, which informed the development of items in the survey instrument and provided rich findings in their own right. Once these data from the focus groups were collected, they were prepared for analysis by being transcribed. Researchers initiated a process of data reduction through coding relevant aspects of the data. This was followed by categorisation into themes. Constant comparison was used to ensure that new themes were noted and that data could be categorised into new themes or fitted in existing ones. Researchers compared their categorisations with each other and discussed any inconsistencies in data categorisation to resolve the location of those data in particular themes or categories.

The items in the online survey investigated the themes arising from the focus groups. Themes included reasons for using IWBs, constraints on using them, attitudes towards their use and accessibility issues. The data linked clearly to the factors identified as first and second order barriers by Ertmer (1999). For example, teachers were asked about access and availability of IWBs and training (first order barriers) and also about beliefs about the technology and levels of competency (second order barriers). Table 2 shows some of the items and their classification as first or second order barriers/enablers.

[Insert Table 2. Examples of items from the survey.]

\section{Findings}

Teachers experienced increasing external pressures from a range of stakeholders to use IWBs, but also perceived a range of pedagogical and organisational benefits, especially in primary education. Consistent with our earlier study (Kearney and Schuck 2008), the major reasons for teachers' adoption of the IWB were its efficiency, access and convenience in the classroom, all first order enablers for adoption. However, the provision of professional development and support, well-known first order barriers, remained a challenge. Schoolbased professional learning options for teachers appear to be available, but not in as pronounced a way as might be expected after many years of external promotion of IWBs in Australian classrooms. Most teachers in the present study expressed a desire for more professional learning on the use of IWBs, especially activities tailored to their own needs. Sharing experiences with colleagues and peer support were perceived by teachers as important factors in their professional learning. Overall, compared to secondary school teachers, primary teachers had more convenient access to IWBs in their classrooms, more positive experiences with and more favourable views relating to the potential for IWBs to enhance learning and support lesson planning and organisation. 


\section{Teacher rationales for use}

There were varying rationales for teachers' use of the IWBs. The focus groups and online survey both revealed that a strong factor for adopting the technology was the need to be 'current'. Another was pressure from others to use the technology, including pressure from employers, principals and school executives, as well as from students and parents expecting or wanting teachers to use IWBs. Quotations from the focus groups, reflecting this pressure from a prescriptive school culture included:

The community was a strong factor. For those who didn't use them, the boss said they must and they did. (Primary school focus group)

We only have an IWB in the class, no other board. (Primary school focus group)

This latter statement indicated that teachers had little choice in the use of the IWB as it was the only place they could present written work to students.

The survey data revealed that over 90 percent of teacher participants held a strong view that it was important to use contemporary technologies in their classrooms (see Table 3). Eighty percent of teachers declared that an important reason for using the IWB was convenience (in the context of a lesson), a first order enabler.

[Insert Table 3. Highest ranking reasons for IWB use ( $\mathrm{n}=200)$. ]

The technology was also considered supportive of teachers' file management, lesson planning and capture as well as providing opportunities for reflection on lessons. However, many teachers were using the IWBs because of their perceived pedagogical benefits. IWBs were viewed by teachers as suitable for providing 'just-in-time', spontaneous Internet access during lessons, an attractive visual mode of presentation, and having appropriate software supporting relevant activities across the K-12 curriculum. Some typical quotations from focus groups, regarding teachers' pedagogical rationales were:

... the effect on children, they need visual stimulation. Year 3 who have always had them differ from year 4 - they lose attention if IWB not on. (Primary school focus group)

Helps with interaction with kids, addresses different learning styles, those who don't write easily get engaged through use of IWB, it is a stimulus then kids discuss topic and then they are able to do the writing task. (Secondary school focus group)

Similarly, there was general consensus in the survey from all teachers that IWBs could enhance pedagogy in new ways, with 87 percent of teachers agreeing that the IWB enabled new types of learning activities (see Table 4). Indeed, 60 percent of teachers thought their teaching approach had changed since using the IWB. Over 80 percent of all teachers indicated they valued the IWB as a vehicle to present media-rich lessons.

Unlike our earlier 2008 study where the IWB was used predominantly for explicit instruction and presentation, many of the examples of IWB use described by teachers in focus groups demonstrated student-centric pedagogies (especially amongst primary teachers, as discussed in the next section), and online technologies such as blogs and Google Earth featured in these descriptions. Teachers in the present study were using IWBs spontaneously to leverage 
serendipitous moments during lessons, for example, to access useful websites during key moments in class discussions:

It is an excellent learning tool. I could put up a map of the world from YouTube and the Internet. And it's interactive. (K-12 school focus group)

It's important to be interactive because of the different learning styles and lots [of students] need the stimulus. Like a maths lesson with a 3D shape on IWB and you drag some squares in and everybody can see what is going on so it is very important for it to be a hands on thing. (K-12 focus group)

The survey indicated that teachers highly valued sharing and re-use of lessons, with almost 90 percent of teachers emphasising the adaptation of others' lesson plans and 75 percent preferring to use the IWB when they could find resources that others had created (see Table 4 below).

[Insert Table 4. Highest ranking perceptions of IWB pedagogical value $(n=200)$. ]

In this sense, the school leaders' expectations noted previously (Kearney and Schuck 2008) that introducing the IWB into their school would act as a catalyst for teacher change and learning about technology, were supported.

\section{Primary and secondary school comparisons}

In this study, we identified considerable differences in IWB experience and usage between Australian secondary schools and primary schools. The focus group data in the study pointed to primary school teacher participants using IWBs more frequently and in more diverse ways than secondary school teacher participants, where access did not seem as high and usage tended to be more presentational.

I use them because the school having them in all classrooms and sharing is strong force to use them. (Primary school focus group)

There is a necessity to be trained. Otherwise we use it as a projector, not using it for the potential of student interaction. I have used it for a video or book or worksheet, so not really taking advantage of the interactivity. I need training on that. (Secondary school focus group)

I used Windows Moviemaker - good for the way a narrative works, integration of the software, pc, instruction and kids putting things together, showing the different parts of a narrative. (Primary school focus group)

The data in the survey indicated that for many teachers in secondary schools, more convenient access to the IWBs is needed. This is somewhat surprising after years of 'top-down' support from school systems. Fifty-six percent of primary school teachers, compared with 28 percent of secondary teachers, had access to an IWB in their classrooms ( $p=.0004$; see Table 5). Also, many secondary teachers noted some constraints such as their booking system and sharing of IWB between classrooms. Hence, it was unsurprising that 49 percent of primary teachers, compared to 26 percent of secondary teachers, claimed that IWBs were a regular feature in their lessons. Quotations which emphasised the importance of access included: "I can see what 
it does but I'm not going to invest the time because I know I'm going to get timetabled in a classroom without one.” (K-12 focus group)

[Insert Table 5. Distribution of access to IWB ( $n=117$ primary; $n=94$ secondary). ]

More primary teachers perceived the IWB as an effective tool for lesson preparation: 62 percent of primary teachers thought the IWB helped them to be more efficient in preparing and revising lesson plans, compared to 37 percent of secondary teachers. Survey data also revealed noticeable differences between primary and secondary teachers' use of applications on the IWBs (see Table 6), with primary teachers using a wider range of applications. For example, primary teachers were far more likely to use games or existing Smartboard software, though presentational applications such as PowerPoint were still popular amongst both groups.

[Insert Table 6. Applications used with the IWB ( $n=117$ primary; $n=94$ secondary): sample items. ]

Primary teacher survey respondents were more likely to use online activities via the IWB, though given the Government supported Connected Classroom initiative that was implemented in NSW government schools from 2007, it was surprising that so few teachers were using the IWB as part of video-conferencing activities. One focus group member explained why this was happening: 'We don't use it [connected classroom] that much. I can't get our class in and have to move tables out etcetera to fit in the whole class'. (Primary school focus group)

The survey indicated that primary teachers were more likely to use an IWB during class discussions or during small group exercises (see Table 7) and were more likely to create and share content.

[Insert Table 7. Uses of the IWB ( $n=117$ primary; $n=94$ secondary): sample items. ]

Seventy-nine percent of primary teachers in the survey thought their class was now more interactive due to their IWB use, compared to 49 percent of secondary teachers, and 65 percent of primary teachers thought their students share more ideas and ask more questions because of the IWB use, compared to 43 percent of secondary teachers. In this way, the primary teacher participants had more favourable views relating to the potential for IWBs to enhance teaching and learning and support lesson planning, sharing and organisation. First-order barriers, such as access and ease-of-use, when using the IWB technology were perceived as less of a problem for this group than they were for secondary teacher participants.

\section{Professional learning}

Although formal professional development opportunities appear to have expanded in recent years, a high portion of teachers (81 percent) in the survey expressed a desire for more professional learning with IWBs. Indeed, 62 percent of teachers said they still found it challenging to learn how to effectively use the IWB and 25 percent of teachers declared they were uncomfortable using it. Only about half (48 percent) of the participants said they had received any formal training in IWB use. Slightly more primary teachers (52 percent) had received such training than secondary teachers (40 percent). Of these respondents, there was a range of training modes reported (see Table 8). 
[Insert Table 8. Modes of training experienced by teachers $(n=200)$. ]

The range of school-based professional learning options for teachers appears to have slightly improved in recent years, for example, user group sessions and online user groups were not mentioned in our previous study (Kearney and Schuck 2008). A minority of teachers (44 percent) responding to the survey said they had received support and training from their school. Whilst the support of colleagues is also often suggested as a source of support for furthering technology adoption only approximately one-third of teachers (34 percent) reported any form of supportive interactions with school-based peers. These surprisingly limited interactions with colleagues were happening through face-to-face communications at school and also through school intranets. User groups extending beyond the school, typically sponsored by corporate entities, were offered for professional learning, but the uptake of these was low, with few (six percent) of our survey respondents indicating online user-groups as a source of their IWB professional development. Teachers also expressed a strong need to further tailor professional development sessions to their differing stages of development.

\section{Discussion}

This study provides evidence that Australian teachers have embraced IWBs and related applications and have diversified associated teaching practices, particularly in primary school education. This development is driven by strong perceptions of pedagogical and organisational benefits, in line with external pressures to use them from other stakeholders, such as principals and system leaders, consistent with Teo's (2014) factor of subjective norm. In agreement with other studies (e.g. Sweeney 2010; Winzenried et al. 2010), a major contribution of IWBs to effective technology integration in primary schools, has been their ease-of-use and effectiveness in addressing first-order barriers to technology adoption, promoting efficiency, organisation and convenience in the classroom, particularly in whole class teaching scenarios. A main reason for teachers in the study initially choosing to use IWBs is to adapt and share colleagues' lesson plans and related files. In this sense, IWBs have provided a catalyst for sharing and re-use of educational resources, as predicted by school leaders in our earlier study (Kearney and Schuck 2008).

Using the Technology Acceptance Model for Pre-Service Teachers (TAMPST) with classroom teachers, Teo (2014) found that there was no discernible difference in acceptance of technology between primary and secondary teachers. An important finding in our study, at odds with Teo's (2014) study, was the marked differences in primary and secondary teachers' perspectives on IWBs. These differences were mainly attributed to the first order barriers of access and professional support, and should be disturbing to Australian secondary school leaders. Primary teachers in this study had more positive perceptions of IWBs and were using them in more pedagogically diverse ways, such as support of games-based learning and small group discussion.

The difference in adoption rates in primary versus secondary schools showed that a critical aspect of adoption of IWBs was ready access to the resource (see Table 5). While Ertmer et al.'s (2012) study indicated that the presence of first order barriers, such as access to resources, has strongly decreased, the current study indicates that first order barriers are still prevalent in Australia, at least in the case of IWB use in secondary schools, and are still influential in teacher adoption of the technology. Given the widespread implementation and government support of IWBs, it is surprising that first-order barriers still play such an important 
role in IWB adoption. There is an urgent imperative to explore whether the differential access experienced by secondary school teachers in this study occurs with other digital technologies as well. Certainly, this study showed that primary school teachers used the IWB in diverse and disruptive ways, for example, to leverage serendipitous 'teaching moments' in lessons and to promote discussion using Web 2.0 software and interactive games. In contrast, the secondary school teachers who did use IWBs tended to use them for more instructionist, presentational reasons. The authors speculate that the current didactic way that IWBs are used by secondary teachers may well be influenced by current external, high stakes assessment regimes to which they have to be accountable, and which do not reward more diverse ways of learning. Other factors such as access, and the lack of opportunity to use the technology as a portal to use of more diverse pedagogies (Schuck and Kearney 2008), or the infrequent offering of professional learning opportunities also may be influential. If these factors continue to dominate secondary education, secondary teachers are likely to remain behind their primary education colleagues in adoption of digital technologies.

We agree with Hennessy and London (2013) that professional learning is key to pedagogical transformation with IWBs. Although teachers were enjoying a number of professional development opportunities in our current study, there was still a strong need identified for more tailored professional learning, including through online professional communities. Teachers in our study called for more opportunities for training and support in the use of the technology. This is concerning, given the significant investment in IWBs by Australian education authorities over a long period of time, and there must be lessons learned. If schools are to embrace and exploit the pedagogical benefits of the next wave of new technologies, particularly ICTs promoted using a 'top-down' approach, school leaders need to make sure first order barriers are adequately addressed and carefully tailored professional learning programs and action learning sessions are designed. This recommendation is not unique to this study (Aubusson et al. 2014; Thomas and Schmid 2010; Warwick and Kershner 2008), nor is it pertinent only for IWB adoption (Hayes et al. 2001).

Given the 'top-down' approaches adopted with technologies such as IWBs, it is not surprising that more formal, often corporate sponsored professional development options appear to dominate 'training' options (e.g. workshops and training sessions, and corporate sponsored user groups). However, given the success of less formal, autonomous arrangements for learning to integrate technology in teaching, such as staff action learning groups (Schuck et al. 2013) and the use of social media to support professional learning networks (Trust 2012; Xerri 2014), it was somewhat surprising that more self-initiated, collaborative professional learning options were not reported to any significant level in this study (see Table 8). Future research could focus on these more informal, 'bottom-up' professional learning opportunities when the next generation of externally promoted technologies are introduced. For example, action learning group strategies such as use of buddy systems, and individually negotiated, authentic immersion activities (Schuck et al. 2013, 16) seem ideal for tailoring teachers' differing stages of development to their professional learning programs.

If professional support and other critical first-order barriers to technology adoption can be addressed, adoption of new technologies is more likely, as evidenced in the primary school teacher data in this study. Such support is likely to provide teachers with extra time and confidence to address more important teaching and learning changes associated with use of emerging technologies. This suggestion is particularly important for externally endorsed technologies, in contrast to those technologies which are likely to have been adopted for personal use before or concurrently with being brought into the classroom by teachers (Schuck 
and Kearney 2008). The personal adoption of less expensive technologies such as social media, mobile devices and video editing is likely to promote more autonomous, flexible approaches in the classroom (Schuck and Kearney 2008), as first order barriers are often far less confronting. This would be interesting to investigate in a future study. Regardless of which approach (top-down, bottom-up) to professional development is taken by stakeholders, we concur with Ertmer et al. (2012) and others that teachers' beliefs are critical to technology integration (Teo 2014; Voogt and Knesek 2008). Longer-term studies of teachers' enacted beliefs (Judson 2006) and the ways that self-initiated professional learning might influence these, are needed to investigate teaching practices with next generation educational technologies that might "challenge long-standing values and beliefs in education" (Law 2008, 431).

\section{Conclusion}

How teachers adopt and use new educational technologies and integrate them into their teaching has been the subject of numerous studies over the last two decades. Some authors have extolled the virtues of ICT for transforming teaching and learning (Bonk and Graham 2006), yet many suggest that ICTs have been largely used to replicate dominant paradigms of teaching (Hedberg 2006; Rushby 2012). As heavy investment in educational technologies continues, there is a need for a strong empirical basis to inform selection of and engagement with the next generation of learning technologies promoted by systems and governments. It is imperative for education stakeholders to learn from the recent 'IWB phenomenon'. First-order barriers such as access must be minimised across the nuanced contexts of primary and especially secondary schooling. Such access has implications for school resource funding. The significant difference in adoption between primary and secondary contexts that was found in this study is an important issue to address where digital technology integration is concerned.

Investment in carefully planned, personalised professional learning, including more flexible, tailored options such as action learning teams, is needed to accompany the inevitable spending on tomorrow's educational technologies, and guide pedagogically diverse applications of these ICTs and dissemination of exemplary practices.

\section{Biographical Notes}

Matthew Kearney is an Associate Professor in Education Technology in the Faculty of Arts and Social Sciences, at the University of Technology, Sydney (UTS). His research specialises in technology-mediated learning in school and teacher education contexts. He is a core member of the STEM Education Futures Research Centre at UTS.

Sandy Schuck is Professor of Education and Director of Research Training in the Faculty of Arts and Social Sciences, at UTS. Her main research interests are in the areas of mathematics education, technology-enhanced learning, teacher learning and teacher attrition and mentoring. She is co-director of the STEM Education Futures Research Centre at UTS

Peter Aubusson is Professor of Education in the Faculty of Arts and Social Sciences, at UTS. His main research interests are in the areas of science and technology education, and teacher learning and development. He is Director of the STEM Education Futures Research Centre at UTS 
Paul F. Burke is an Associate Professor in the Discipline of Marketing and Deputy Director of the Business Intelligence \& Data Analytics (BIDA) Research Centre located in UTS Business School. He specialises in choice modelling, experimental design and consumer behaviour.

\section{Acknowledgements}

This research study was funded jointly by Electroboard Pty Ltd and a UTS Partnership Award. The findings were not in any way influenced by the sponsors.

\section{References}

Aubusson, P., P. Burke, S. Schuck, M. Kearney, and B. Frischknecht, 2014. "Teachers Choosing Rich Tasks: The Moderating Impact of Technology on Student Learning, Enjoyment and Preparation." Educational Researcher 43 (5): 219-229.

Ayhan Kursat, E., I. Muge, and K. Sukru. 2015. "Learning Mathematics with Interactive Whiteboards and Computer-Based Graphing Utility." Journal of Educational Technology \& Society 18 (2): 299-312.

Bennett, S., and L. Lockyer. 2008. "A Study of Teachers' Integration of Interactive Whiteboards into Four Australian Primary School Classrooms." Learning, Media and Technology 33 (4): 289-300. doi: 10.1080/17439880802497008

Blackwell, C.K., A. Lauricella, and E. Wartella. 2014. "Factors Influencing Digital Technology Use in Early Childhood Education." Computers \& Education 77: 82- 90. doi: 10.1016/j.compedu.2014.04.013

Bonk, C.J., and C. Graham. 2006. The Handbook of Blended Learning Environments: Global Perspectives, Local Designs. San Francisco: Jossey-Bass/Pfeiffer.

Buabeng-Andoh, C. 2012. "Factors Influencing Teachers' Adoption and Integration of Information and Communication Technology into Teaching: A Review of the Literature." International Journal of Education and Development using Information and Communication Technology (IJEDICT) 8 (1): 136-155.

Bull, G., A. Thompson, M. Searson, J. Garofalo, J. Park, C. Young, and J. Lee. 2008. "Connecting Informal and Formal Learning: Experiences in the Age of Participatory Media." Contemporary Issues in Technology and Teacher Education 8 (2): 100-107.

Clarke, C. 2004. Opening address to the BETT Conference, London, January 7, 2004.

Cogill, J. 2010. "A Model of Pedagogical Change for the Evaluation of Interactive Whiteboard Practice." In Interactive Whiteboards for Education: Theory, Research and Practice, edited by M. Thomas, and E. C. Schmid, 162-178. Hershey, PA: Information Science Reference. 
Cuban, L., H. Kirkpatrick, and C. Peck. 2001. "High Access and Low Use of Technologies in High School Classrooms: Explaining an Apparent Paradox." American Educational Research Journal 38 (4): 813-834.

Department of Education, Employment and Workplace Relations. 2010. ICT Innovation Fund Guidelines 2010-2012. Accessed July 212017 from https://docs.education.gov.au/node/264

Dunn, K., and G. Rakes. 2010. "Learner-centeredness and Teacher Efficacy: Predicting Teachers' Consequence Concerns Regarding the use of Technology in the Classroom." Journal of Technology and Teacher Education 18 (1): 57-83. Chesapeake, VA: Society for Information Technology \& Teacher Education.

Ertmer, P. A. 1999. "Addressing First- and Second-Order Barriers to Change: Strategies for Technology Integration.” Educational Technology Research and Development 47 (4) 47-61. doi: 10.1007/BF02299597

Ertmer, P.A. 2005. "Teacher Pedagogical Beliefs: The Final Frontier in our Quest for Technology Integration?” Educational Technology Research and Development 53 (4): 25-39.

Ertmer, P.A., and A. Ottenbreit-Leftwich. 2010. "Teacher Technology Change: How Knowledge, Confidence, Beliefs, and Culture Intersect." Journal of Research on Technology in Education 42 (3): 255-284. doi: 10.1080/15391523.2010.10782551

Ertmer, P.A., A. Ottenbreit-Leftwich, O. Sadik, E. Sendurur, and P. Sendurur. 2012. "Teacher Beliefs and Technology Integration Practices: A Critical Relationship." Computers \& Education 59 (2): 423-435. doi:10.1016/j.compedu.2012.02.001

Erickson, F. 1986. "Qualitative Methods in Research on Teaching.” In Handbook of Research on Teaching, edited by M. Wittrock, 119-161. New York: Macmillan.

Gillen, J., J. Staarman, K. Littleton, N. Merce, and A. Twiner. 2007. “A 'Learning Revolution'? Investigating Pedagogic Practice around Interactive Whiteboards in British Primary Classrooms." Learning, Media and Technology 32 (3): 243-256. doi: 10.1080/17439880701511099

Gray, C. 2010. “Meeting Teachers' Real Needs: New Tools in The Secondary Modern Foreign Languages Classroom." In Interactive Whiteboards for Education: Theory, Research and Practice, edited by M. Thomas and E. Cutrim-Schmid, 69-85. Hershey, PA: Information Science Reference.

Greenhow, C., and C. Lewin. 2016. "Social Media and Education: Reconceptualizing the Boundaries of Formal and Informal Learning." Learning, Media and Technology 41 (1): 630 . 
Hayes, D., S. Schuck, G. Segal, J. Dwyer, and C. McEwen 2001. "Net Gain? The Integration of Computer-Based Learning in Six NSW Government Schools, 2000." Sydney: The University of Technology, Sydney.

Hedberg, J. 2006. "E-Learning Futures? Speculations for a Time yet to Come." Studies in Continuing Education 28 (2): 171-183. doi: 10.1080/01580370600751187

Hennessy, S., and L. London. 2013. "Learning from International Experiences with Interactive Whiteboards: The Role of Professional Development in Integrating the Technology" (Report No. 89). OECD Publishing.

Higgins, S., G. Beauchamp, and D. Miller. 2007. "Reviewing the Literature on Interactive Whiteboards." Learning, Media and Technology 32 (3): 213-225. doi: 10.1080/17439880701511040

Hillman, T. 2014. "Finding Space for Student Innovative Practices with Technology in the Classroom.” Learning, Media and Technology 39 (2): 169-183. doi: 10.1080/17439884.2013.803256

Judson, E. 2006. "How Teachers Integrate Technology and their Beliefs about Learning: Is There A Connection?" Journal of Technology and Teacher Education 14 (3): 581-597.

Kearney, M., and S. Schuck. 2008. "Exploring Pedagogy with Interactive Whiteboards in Australian Schools." Australian Educational Computing 23 (1): 8-13.

Kennewell, S. 2006. Reflections on the Interactive Whiteboard Phenomenon: A Synthesis of Research from the UK. Paper presented at the AARE Conference, Adelaide, Australia.

Law, N. 2008. "Teacher Learning Beyond Knowledge For Pedagogical Innovations With ICT." In International Handbook of Information Technology in Primary and Secondary Education, edited by J. Voogt and G. Knezek, 425-434. New York: Springer Science+Business Media.

Lincoln, Y., and E. Guba. 1985. Naturalistic Inquiry. Newbury Park: Sage Publications.

Newhouse, C. 2014. "Learning with Portable Digital Devices in Australian Schools: 20 Years On!" Australian Educational Researcher 41: 471-483. doi: 10.1007/s13384-013-0139-3

Perrotta, C. 2013. "Do School Level Factors Influence the Educational Benefits of Digital Technology? A Critical Analysis of Teachers' Perceptions." British Journal of Educational Technology 44 (2): 314-327. doi: 10.1111/j.1467-8535.2012.01304.x

Royle, K., S. Stager, and J. Traxler, 2014. "Teacher development with mobiles: Comparative critical factors.” Prospects 44: 29-42. http://dx.doi.org/10.1007/s11125-013-9292-8

Rushby, N. 2012. "Editorial: An Agenda for Mobile Learning." British Journal of Educational Technology 43 (3) 355-356. doi: 10.1111/j.1467-8535.2012.01313.x 
Salomon, G., and D. Perkins. 1998. "Individual and Social Aspects of Learning." Review of Research in Education 23: 1-24.

Schuck, S., P. Aubusson, M. Kearney, and K. Burden. 2013. "Mobilising Teacher Education: A study of a Professional Learning Community." Teacher Development 17 (1): 1-18

Schuck, S., and M. Kearney. 2008. "Classroom-based Use of Two Educational Technologies: A Socio-cultural Perspective." Contemporary Issues in Technology and Teacher Education: Current Practices 8 (4): 394-406.

Sweeney, T. 2010. "Transforming Pedagogy Through Interactive Whiteboards: Using Activity Theory to Understand Tensions in Practice." Australian Educational Computing 24 (2): $28-34$.

Teo, T. 2014. "Unpacking Teachers' Acceptance of Technology: Tests of Measurement Invariance and Latent Mean Differences." Computers \& Education 75:127-135. doi: 10.1016/j.compedu.2014.01.014

Thomas, M., and E. Schmid. 2010. Interactive Whiteboards for Education: Theory, Research and Practice. Hershey, PA: Information Science Reference.

Trust, T. 2012. "Professional Learning Networks Designed for Teacher Learning." Journal of Digital Learning in Teacher Education 28 (4): 133-138.

Türel, Y. K., and T. Johnson. 2012. "Teachers' Belief and Use of Interactive Whiteboards for Teaching and Learning." Journal of Educational Technology \& Society 15 (1): 381-394.

Voogt, J., and G. Knezek. 2008. "IT in Primary and Secondary Education: Emerging Issues." In International Handbook of Information Technology in Primary and Secondary Education, edited by J. Voogt, and G. Knezek, xxix-xxxix. New York: Springer Science+Business Media.

Warwick, P., and R. Kershner. 2008. "Primary Teachers' Understanding of the Interactive Whiteboard as a Tool for Children's Collaborative Learning and Knowledge-Building." Learning, Media and Technology 33 (4): 269-287. doi: 10.1080/17439880802496935

Weston, M. E., and A. Bain. 2010. "The End of Techno-Critique: The Naked Truth about 1:1 Laptop Initiatives and Educational Change." Journal of Technology, Learning, and Assessment 9 (6): 1-25.

Winzenried, A., B. Dalgarno, and J. Tinkler. 2010. "The Interactive Whiteboard: A Transitional Technology Supporting Diverse Teaching Practices." Australian Journal of Educational Technology 26 (4): 534-552. 
Wong, K., T. Teo, and P. Goh. 2014. "Development of The Interactive Whiteboard Acceptance Scale (IWBAS): An Initial Study." Educational Technology \& Society 17 (4): 268-277.

Xerri, D. 2014. "Teachers' Use of Social Networking Sites for Continuing Professional Development." In The Social Classroom: Integrating Social Network Use in Education, edited by G. Mallia, 441-464. Hershey, PA: IGI Global.

\section{Tables}

Table 1. Participants' IWB experience level ( $n=117$ primary; $n=94$ secondary).

\begin{tabular}{|l|c|c|}
\hline I would characterise my experience with IWBs as: & \% Primary & \% Secondary \\
\hline Introductory & 49 & 67 \\
\hline Intermediate & 41 & 23 \\
\hline Advanced & 10 & 10 \\
\hline
\end{tabular}

Table 2. Examples of items from the survey.

\begin{tabular}{|l|l|}
\hline My experience using IWBs: & \multicolumn{1}{|c|}{ Type of barrier } \\
\hline Item & First order enabler/barrier - training \\
\hline $\begin{array}{l}\text { I received support and training through } \\
\text { online user groups }\end{array}$ & $\begin{array}{l}\text { Second order enabler/barrier - pedagogical } \\
\text { approach }\end{array}$ \\
\hline $\begin{array}{l}\text { I use an IWB for teacher delivery to whole } \\
\text { class }\end{array}$ & First order enabler/barrier - access \\
\hline $\begin{array}{l}\text { An IWB is a regular feature in my } \\
\text { classroom }\end{array}$ & Second order enabler/barrier - beliefs \\
\hline $\begin{array}{l}\text { I use IWBs because it helps the students } \\
\text { learn more }\end{array}$ & \\
\hline
\end{tabular}

Table 3. Highest ranking reasons for IWB use $(n=200)$.

\begin{tabular}{|l|c|}
\hline Important reasons to use the IWB & \% Agree \\
\hline $\begin{array}{l}\text { Teachers should keep up with modern } \\
\text { technology }\end{array}$ & 93 \\
\hline It improves student learning & 80 \\
\hline It is convenient & 80 \\
\hline
\end{tabular}


Table 4. Highest ranking perceptions of IWB pedagogical value $(n=200)$.

\begin{tabular}{|l|c|}
\hline $\begin{array}{l}\text { A valuable part of the IWB for me as a teacher } \\
\text { is... }\end{array}$ & \% Agree \\
\hline $\begin{array}{l}\text { I can engage the students in novel learning } \\
\text { activities }\end{array}$ & 89 \\
\hline I can reuse the lesson plans & 87 \\
\hline $\begin{array}{l}\text { I am able to teach things in new ways (novel } \\
\text { pedagogy) }\end{array}$ & 84 \\
\hline It is easy to present media rich lessons & 76 \\
\hline I can adapt lesson plans from others & \\
\hline
\end{tabular}

Table 5. Distribution of access to IWB ( $n=117$ primary; $n=94$ secondary).

\begin{tabular}{|l|c|c|}
\hline Nature of access to IWB & $\begin{array}{c}\% \text { Positive } \\
\text { Responses } \\
\text { (Primary) }\end{array}$ & $\begin{array}{c}\% \text { Positive } \\
\text { Responses } \\
\text { (Secondary) }\end{array}$ \\
\hline An IWB is in my classroom & 56 & 28 \\
\hline $\begin{array}{l}\text { I can use an IWB if I book the } \\
\text { classroom where it is installed }\end{array}$ & 21 & 38 \\
\hline IWB can be brought in if booked & 3 & 20 \\
\hline I don't have access to an IWB & 15 & 5 \\
\hline I have never seen an IWB & 4 & 9 \\
\hline
\end{tabular}

Table 6. Applications used with the IWB ( $\mathrm{n}=117$ primary; $\mathrm{n}=94$ secondary): sample items.

\begin{tabular}{|l|c|c|}
\hline Applications used on IWB & $\begin{array}{c}\text { \% Agree } \\
\text { (Primary) }\end{array}$ & $\begin{array}{c}\text { \% Agree } \\
\text { (Secondary) }\end{array}$ \\
\hline Drawing, notes, etc. & 87 & 64 \\
\hline Connection to Internet & 81 & 61 \\
\hline Games & 73 & 33 \\
\hline Smartboard resources & 69 & 39 \\
\hline Video playback & 62 & 57 \\
\hline PowerPoint & 61 & 66 \\
\hline Video conferencing & 11 & 3 \\
\hline
\end{tabular}


Table 7. Uses of the IWB ( $\mathrm{n}=117$ primary; $\mathrm{n}=94$ secondary): sample items.

\begin{tabular}{|l|c|c|}
\hline I commonly use the IWB... & $\begin{array}{c}\text { \% Agree } \\
\text { (Primary) }\end{array}$ & $\begin{array}{c}\text { \% Agree } \\
\text { (Secondary) }\end{array}$ \\
\hline For teacher delivery to the whole class & 87 & 69 \\
\hline To show videos to the class & 83 & 67 \\
\hline During classroom discussions & 77 & 40 \\
\hline $\begin{array}{l}\text { With the class or groups of students } \\
\text { gathered close around the board }\end{array}$ & 70 & \\
\hline
\end{tabular}

Table 8. Modes of training experienced by teachers $(n=200)$.

\begin{tabular}{|l|c|}
\hline I received support and training ... & \% Agree \\
\hline At my school & 44 \\
\hline $\begin{array}{l}\text { Through interactions with other } \\
\text { teachers }\end{array}$ & 34 \\
\hline $\begin{array}{l}\text { Through user group sessions at other } \\
\text { schools }\end{array}$ & 13 \\
\hline Through online user groups & 6 \\
\hline
\end{tabular}

